\title{
PENGARUH APLIKASI BAHAN ORGANIK TERHADAP PERTUMBUHAN DAN HASIL BEBERAPA VARIETAS SORGUM (Sorghum bicolor [L] Moench)
}

\author{
Ryzkita Prima Pramanda, Kuswanta F. Hidayat, Sunyoto \& M. Kamal \\ Jurusan Agroteknologi, Fakultas Pertanian Universitas Lampung \\ Jl. Prof. Soemantri Brodjonegoro, No. 1 bandar lampung 35145 \\ Email: RyzkitaPramanda@yahoo.com
}

\begin{abstract}
ABSTRAK
Sorghum (Sorghum bicolor [L] Moench) adalah tanaman serealia yang memiliki potensi untuk dikembangkan sebagai sumber bahan pangan mendukung program diversifikasi pangan. Untuk meningkatkan pertumbuhan dan hasil tanaman sorgum maka perlu upaya pengembangan teknik budidaya seperti penambahan bahan organik dan penggunaan varietas unggul. Tujuan dari penelitian ini adalah untuk; mengetahui dosis pemberian bahan organik terbaik untuk pertumbuhan dan hasil tanaman sorgum; mengetahui varietas tanaman sorgum yang menunjukan pertumbuhan dan hasil terbaik ; mengetahui pengaruh interaksi antara dosis bahan organik dan varietas yang digunakan terhadap pertumbuhan dan hasil tanaman sorgum. Penelitian ini dilaksanakan di Balai Pengkajian Teknologi Pertanian (BPTP) Unit Kebun Percobaan Natar, Desa Negara Ratu, Kecamatan Natar, Kabupaten Lampung Selatan pada bulan Mei sampai September 2013. Perlakuan disusun secara faktorial dalam rancangan acak kelompok dengan 3 ulangan. Petak utama adalah dosis bahan organik (b) yang terdiri atas 4 taraf yaitu 0 ton ha ${ }^{-1}(\mathrm{~b} 0), 5$ ton ha' ${ }^{-1}$ (b1), 10 ton ha' ${ }^{-1}$ (b2) dan 15 ton ha-1 (b3). Anak petak adalah varietas sorgum (g) yaitu Numbu (g1), Keller (g2), dan Wray (g3). Sorgum ditanam dengan jarak tanam $80 \mathrm{~cm}$ x $20 \mathrm{~cm}$ pada setiap petak percobaan yang berukuran $4 \mathrm{~m} \times 4 \mathrm{~m}$. Pupuk yang digunakan adalah Urea, SP-36 dan KCl masing-masing dengan dosis 100, 100 dan $150 \mathrm{~kg} \mathrm{ha}^{-1}$. Pemberian Urea dilakukan secara bertahap yaitu 2 minggu setelah tanam (mst) dan 6 mst. Hasil penelitian menunjukkan bahwa; aplikasi bahan organik meningkatkan pertumbuhan dan hasil tanaman sorgum. Hasil sorgum tertinggi dicapai pada dosis 15 ton ha ${ }^{-1}$; varietas Numbu menunjukkan keragaan komponen hasil bobot biji/ malai terbaik, sedangkan produksi biomassa terbaik ditunjukkan oleh varietas Keller dan Wray; kombinasi penggunaan bahan organik dan varietas yang tepat untuk memperoleh hasil biji sorgum tertinggi adalah dosis 15 ton ha $^{-1}$ dengan varietas Numbu.
\end{abstract}

Kata kunci: bahan organik, pertumbuhan hasil, sorgum, varietas.

\section{PENDAHULUAN}

Berdasarkan Sensus Penduduk 2010, jumlah penduduk Indonesia sudah mencapai 237,6 juta jiwa. Kebutuhan pangan senantiasa meningkat seiring dengan peningkatan jumlah penduduk. Hal ini menyebabkan ketidakstabilan pangan antara kebutuhan dan pemenuhannya secara nasional (Purwaningsih, 2008).

Sorgum (Sorghum bicolor [L.] Moench) merupakan salah satu jenis tanaman serealia yang mempunyai potensi besar untuk dikembangkan di Indonesia karena mempunyai daerah adaptasi yang luas. Tanaman sorgum toleran terhadap kekeringan dan genangan air, dapat berproduksi pada lahan marginal, serta relatif tahan terhadap gangguan hama/penyakit (Sirappa, 2003)

Sebagian besar tanah lahan kering memiliki kesuburan tanah dan kandungan bahan organik yang rendah. Tanpa penambahan bahan organik yang memiliki kandungan hara lengkap, kesuburan dan produktivitas tanah sulit ditingkatkan. Beberapa manfaat pemberian bahan organik adalah meningkatkan kandungan humus tanah, mengurangi pencemaran lingkungan, mengurangi pengurasan hara yang terangkut dalam bentuk panenan dan erosi, memperbaiki sifat-sifat tanah (Swift \& Sanchez, 1984 dalam Prihastanti, 2010), dan memperbaiki kesehatan tanah (Logan, 1990 dalam Prihastanti, 2010). Namun pemberian bahan oganik tetap harus memperhatikan efisiensi penggunaannya. Harus diketahui dosis pupuk optimum yang harus diberikan pada tanaman sorgum, sedangkan masih sedikit sekali sumber pustaka yang memberikan dosis pupuk kandang terbaik bagi tanaman sorgum.

Berdasarkan penelitian sebelumnya yaitu (Ngawit dan Hanan, M, 2007 dalam Zulkifli, 2012 ) menyatakan bahwa pemberian pupuk kandang sapi meningkatkan pertumbuhan tanaman jagung, terutama jumlah daun hijau selama fase pengisian biji, mempercepat umur keluar malai dan rambut tongkol serta meningkatkan hasil, komponen hasil dan indek panen. Pertumbuhan tanaman dipengaruhi oleh faktor genetik dan lingkungan. Berdasarkan penelitian Sucipto (2010) Pemupukan memberikan pengaruh yang berbeda terhadap tinggi tanaman, jumlah daun dan kadar brix. Pada tinggi 
tanaman Wray menunjukkan tinggi tanaman terbaik dan berbeda nyata dengan Keller dengan peningkatan sebesar 4,9\%. Pada jumlah daun dan kadar brix hasil tertinggi ditunjukkan oleh varietas Keller dengan peningkatan $33,8 \%$ dan $17,6 \%$.

Penelitian ini bertujuan: untuk (1) mengetahui dosis pemberian bahan organik terbaik untuk pertumbuhan dan hasil tanaman sorgum (2) mengetahui varietas tanaman sorgum yang memiliki pertumbuhan dan hasil terbaik (3) mengetahui pengaruh interaksi antara dosis bahan organik dan jenis varietas yang digunakan terhadap pertumbuhan dan hasil tanaman sorgum.

\section{BAHAN DAN METODE}

Penelitian ini dilaksanakan di Balai Pengkajian Teknologi Pertanian (BPTP) Unit Kebun Percobaan Natar, Desa Negara Ratu, Kecamatan Natar, Kabupaten Lampung Selatan yang dilaksanakan sejak bulan Mei sampai bulan September 2013. Bahan-bahan dan alat yang digunakan adalah tiga varietas sorgum (Numbu, Keller, dan Wray), pupuk Urea, SP36, KCl, alat pengolah tanah, golok, sabit, carter, ember, gayung, alat penyedot air, selang, mikrometer sekrup, label sampel, gunting, buku, alat tulis, meteran, timbangan, dan oven. Perlakuan disusun secara factorial dengan split plot dalam RAK dengan tiga ulangan. Petak utama adalah dosis bahan organik (B) yang terdiri atas 4 taraf yaitu 0 ton ha-1 (b0), 5 ton ha' ${ }^{-1}$ (b1), 10 ton ha-1 (b2) dan 15 ton $\mathrm{ha}^{-1}(\mathrm{~b} 3)$. Anak petak adalah varietas sorgum (G) yaitu Numbu (g1), Keller (g2), dan Wray (g3). Rincian perlakuan disajikan pada Tabel 1.

Tabel 1. Susunan perlakuan dalam percobaan pengaruh pengaruh aplikasi bahan organik terhadap pertumbuhan dan hasil beberapa varietas sorgum (Sorghum bicolor [L.] Moench)

\begin{tabular}{cl}
\hline Perlakuan & \multicolumn{1}{c}{ Keterangan } \\
\hline b0g1 & BO Dosis 0 ton/ha + Varietas Numbu \\
b0g2 & BO Dosis 0 ton/ha + Varietas Kell er \\
b0g3 & BO Dosis 0 ton/ha + Varietas Wray \\
b1g1 & BO Dosis 5 ton/ha + Varietas Numbu \\
b1g2 & BO Dosis 5 ton/ha + Varietas Kell er \\
b1g3 & BO Dosis 5 ton/ha + Varietas Wray \\
b2g1 & BO Dosis 10 ton/ha + Varietas Numbu \\
b2g2 & BO Dosis 10 ton/ha + Varietas Keller \\
b2g3 & BO Dosis 10 ton/ha + Varietas Wray \\
b3g1 & BO Dosis 15 ton/ha + Varietas Numbu \\
b3g2 & BO Dosis 15 ton/ha + Varietas Keller \\
b3g3 & BO Dosis 15 ton/ha + Varietas Wray \\
\hline
\end{tabular}

Lahan yang telah diolah kemudian dibuat petak percobaan yang masing-masing berukuran $4 \mathrm{~m} \mathrm{x} 4 \mathrm{~m}$. Sorgum ditanam dalam petakan dengan jarak tanam 80 $\mathrm{cm}$ x $20 \mathrm{~cm}$. Pemberian bahan organik saat pengolahan tanah. Pupuk yang digunakan adalah Urea, SP-36 dan $\mathrm{KCl}$ masing-masing dengan dosis 100, 100 dan $150 \mathrm{~kg}$ ha $^{-1}$. Pemupukan Urea, SP36, dan $\mathrm{KCl}$ dilakukan dengan cara larikan dengan takaran 320, 160 dan 240 g per petakan masing-masing untuk Urea, SP36 dan $\mathrm{KCl}$. Pemupukan Urea dilakukan sebanyak 2 kali pada 2 MST dan 6 MST, yaitu masing-masing dengan takaran $160 \mathrm{~g}$ petak $^{-1}$, sedangkan SP36 dan $\mathrm{KCl}$ diberikan sekaligus pada saat tanaman berumur 2 minggu. Penjarangan dilakukan pada saat tanaman sorgum berumur 4 MST, setiap lubang tanam hanya terdapat 1 tanaman per lubang. Penyiraman dan pengendalian hama penyakit termasuk pengendalian gulma dilakukan pada saat diperlukan.

Variabel yang diamati meliputi : (1) tinggi tanaman, (2) jumlah daun, (3) diameter batang, (4) jumlah tanaman panen, (5) bobot brangkasan basah, (6) bobot brangkasan kering, (7) panjang malai, (8) jumlah biji/malai, (9) bobot biji basah/malai, dan (10) bobot 100 butir pada kadar air $14 \%$. Semua data dianalisis dengan sidik ragam dan perbedaan nilai tengah antar perlakuan diuji dengan BNT pada taraf $5 \%$

\section{HASIL DAN PEMBAHASAN}

Hasil penelitian menunjukkan bahwa perlakuan bahan organik memberikan pengaruh yang nyata terhadap tinggi tanaman, jumlah daun, diameter batang (Tabel 2, 3 dan 4). Pada pengamatan tinggi tanaman terdapat pengaruh yang nyata untuk pemberian berbagai dosis bahan organik pada 6,7,8 dan 9 mst. Perlakuan 15 ton ha ${ }^{-1}$ menunjukkan hasil yang lebih baik namun tidak berbeda nyata dengan perlakuan 10 ton ha-1 (Tabel 2). Pada minggu ke 10 ternyata penggunaan bahan organik tidak berpengaruh nyata terhadap tinggi tanaman. Hal ini mungkin disebabkan oleh pertumbuhan tinggi tanaman yang telah mencapai titik maksimumnya. Selain penggunaan bahan organik, varietas juga memberikan pengaruh yang nyata terhadap tinggi tanaman pada 7 dan 10 mst. Tinggi tanaman terbaik ditunjukkan oleh varietas Keller (Tabel 2).

Pemberian bahan organik juga memberikan pengaruh yang nyata terhadap jumlah daun pada 6,7 dan 8 mst. Jumlah daun terbanyak ditunjukkan oleh perlakuan 15 ton/ha namun tidak berbeda nyata dengan perlakuan 10 ton ha ${ }^{-1}$ (Tabel 3). Sedangkan penggunaan varietas memberikan pengaruh yang nyata terhadap jumlah daun pada 7, 8, 9 dan 10 mst. Hasil terbaik 
Tabel 2. Pengaruh bahan organik dan varietas terhadap tinggi tanaman sorgum pada 6,7,8,9 dan 10 mst

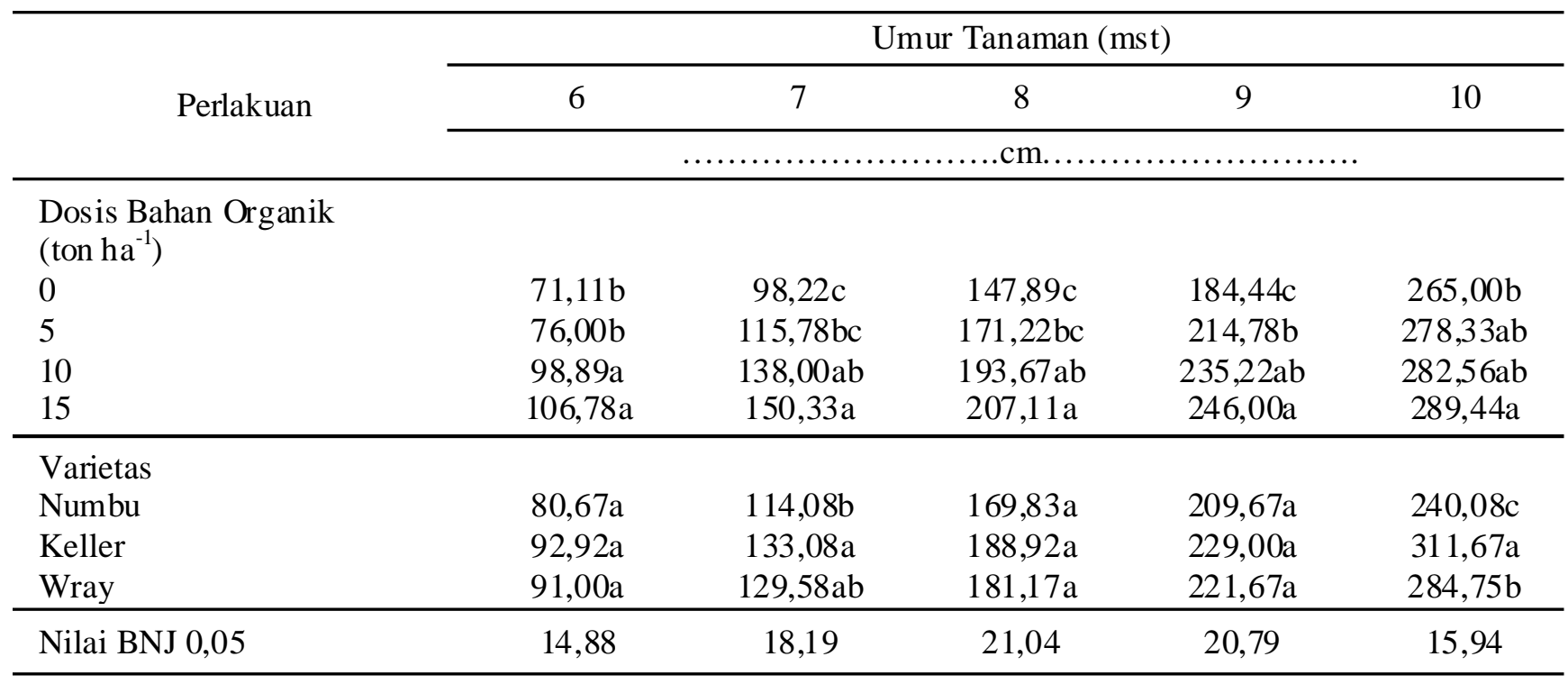

Keterangan: Angka-angka yang diikuti oleh huruf yang sama pada kolom dan perlakuan yang sama berbeda tidak nyata menurut uji BNJ pada taraf $5 \%$.

Tabel 3. Pengaruh bahan organik dan varietas terhadap jumlah daun tanaman sorgum pada 6,7,8,9 dan 10 mst

\begin{tabular}{|c|c|c|c|c|c|}
\hline \multirow{3}{*}{ Perlakuan } & \multicolumn{5}{|c|}{ Umur Tanaman (mst) } \\
\hline & 6 & 7 & 8 & 9 & 10 \\
\hline & \multicolumn{5}{|c|}{ n......................helai.......................... } \\
\hline \multicolumn{6}{|c|}{ Dosis Bahan Organik (ton/ha) } \\
\hline 0 & $7,11 b$ & $8,44 \mathrm{c}$ & $8,67 \mathrm{c}$ & $9,22 \mathrm{c}$ & $7,44 \mathrm{~b}$ \\
\hline 5 & $7,44 b$ & $9,00 \mathrm{bc}$ & $9,78 b c$ & $10,11 \mathrm{bc}$ & $8,00 \mathrm{ab}$ \\
\hline 10 & $8,89 \mathrm{a}$ & $9,89 \mathrm{ab}$ & $10,89 \mathrm{ab}$ & $10,33 \mathrm{a}$ & $8,22 \mathrm{ab}$ \\
\hline 15 & $9,22 \mathrm{a}$ & $10,89 \mathrm{a}$ & $11,44 \mathrm{a}$ & $11,11 \mathrm{a}$ & $8,67 \mathrm{a}$ \\
\hline \multicolumn{6}{|l|}{ Varietas } \\
\hline Numbu & $7,83 \mathrm{a}$ & $8,83 \mathrm{~b}$ & $9,33 b$ & $9,25 b$ & $6,33 c$ \\
\hline Keller & $8,42 \mathrm{a}$ & $9,92 \mathrm{a}$ & $10,67 \mathrm{a}$ & $10,83 \mathrm{a}$ & $9,42 \mathrm{a}$ \\
\hline Wray & $8,25 \mathrm{a}$ & $9,92 \mathrm{a}$ & $10,58 \mathrm{a}$ & $10,50 \mathrm{a}$ & $8,50 \mathrm{~b}$ \\
\hline Nilai BNJ 0,05 & 0,70 & 0,80 & 1,10 & 0,71 & 0,90 \\
\hline
\end{tabular}

Keterangan: Angka-angka yang diikuti oleh huruf yang sama pada kolom dan perlakuan yang sama berbeda tidak nyata menurut uji BNJ pada taraf $5 \%$.

ditunjukkan oleh varietas Keller namun pada 7, 8 dan 9 mst tidak berbeda nyata dengan Wray. Penambahan jumlah daun meningkat setiap minggunya, namun mulai mengalami penurunan pada minggu ke 9 dan 10 (Tabel 3). Hal ini sejalan dengan pendapat Nasaruddin (2010), pertumbuhan dan perkembangan daun pada awal pertumbuhan tanaman akan terus bertambah sejalan dengan pertambahan umur tanaman. Penambahan luas daun akan berkurang atau terhenti pada saat tanaman memasuki fase pembungaan. Hal ini juga sejalan dengan pendapat Safitri et al. (2010) bahwa jumlah daun telah mencapai maksimal yaitu berkisar antar 6-12 helai, sehingga unsur hara yang tersedia lebih ditujukan untuk pembentukan biji.

Bahan organik memberikan pengaruh yang nyata pada setap minggu pengamatan diameter batang. Diameter batang terbaik ditunjukkan oleh perlakuan 15 ton ha $^{-1}$ (Tabel 4). Pemberian pupuk kandang dalam jumlah banyak dapat mendukung ketersediaan unsur hara sehingga pertumbuhan diameter batang mencapai 
Tabel 4. Pengaruh bahan organik dan varietas terhadap diameter batang tanaman sorgum pada 8,9 dan 10 mst

\begin{tabular}{|c|c|c|c|}
\hline \multirow{3}{*}{ Perlakuan } & \multicolumn{3}{|c|}{ Umur Tanaman (mst) } \\
\hline & 8 & 9 & 10 \\
\hline & \multicolumn{3}{|c|}{$\ldots \ldots \ldots \ldots \ldots \ldots \ldots \ldots \ldots \ldots \ldots \ldots$} \\
\hline \multicolumn{4}{|c|}{ Dosis Bahan Organik (ton ha $^{-1}$ ) } \\
\hline 0 & $1,64 d$ & $1,80 \mathrm{~d}$ & $1,82 \mathrm{~d}$ \\
\hline 5 & $1,89 \mathrm{c}$ & $2,15 \mathrm{c}$ & $2,28 \mathrm{c}$ \\
\hline 10 & $2,12 b$ & $2,42 b$ & $2,54 \mathrm{~b}$ \\
\hline 15 & $2,39 a$ & $2,68 \mathrm{a}$ & $2,92 \mathrm{a}$ \\
\hline \multicolumn{4}{|l|}{ Varietas } \\
\hline Numbu & $1,90 \mathrm{~b}$ & $2,10 \mathrm{~b}$ & $2,16 \mathrm{~b}$ \\
\hline Keller & $2,20 \mathrm{a}$ & $2,39 a$ & $2,52 \mathrm{a}$ \\
\hline Wray & $1,94 b$ & $2,29 \mathrm{a}$ & $2,50 \mathrm{a}$ \\
\hline Nilai BNJ 0,05 & 0,16 & 0,18 & 0,12 \\
\hline
\end{tabular}

Keterangan: Angka-angka yang diikuti oleh huruf yang sama pada kolom dan perlakuan yang sama berbeda tidak nyata menurut uji BNJ pada taraf $5 \%$.

optimal.Hal ini sejalan dengan pendapat yang dikemukakan Harjadi (1993) perbesaran sel membutuhkan karbohidrat, air serta hormon dan vitaminvitamin. Hal ini sangat erat kaitannya dengan serapan air serta zat hara. Penggunaan varietas juga berpengaruh nyata pada setiap minggu pengamatan. Diameter batang terbaik ditunjukkan oleh varietas Keller, namun pada 9 dan 10 mst tidak berbeda nyata dengan varietas Wray (Tabel 4).
Pada pengamatan bobot basah tanaman, perlakuan bahan organik tidak memberikan pengaruh yang nyata, namun penggunaan varietas memberikan pengaruh yang nyata. Bobot basah tanaman terbaik ditunjukkan oleh varietas Keller namun tidak berbeda nyata dengan varietas Wray ( Tabel 5). Hal ini berbanding terbalik dengan pernyataan Safitri et al. (2010) pemberian berbagai dosis pupuk kandang ayam memberikan pengaruh yang berbeda nyata terhadap

Tabel 5. Pengaruh bahan organik dan varietas terhadap bobot basah, bobot kering dan panjang malai tanaman sorgum pada umur $12 \mathrm{mst}$

\begin{tabular}{lccc}
\hline \multirow{2}{*}{ Perlakuan } & $\begin{array}{c}\text { Bobot Brangkasan } \\
\text { Basah }\end{array}$ & $\begin{array}{c}\text { Bobot Brangkasan } \\
\text { Kering }\end{array}$ & Panjang Malai \\
\cline { 2 - 4 } & Kg per 5 tanaman & Kg per 5 tanaman & $\mathrm{cm}$ \\
\hline Dosis Baan Organik $\left(\right.$ ton $\left.^{-1}{ }^{-1}\right)$ & & & \\
0 & $1,94 \mathrm{~b}$ & $0,55 \mathrm{~b}$ & $22,24 \mathrm{a}$ \\
5 & $2,66 \mathrm{ab}$ & $0,72 \mathrm{ab}$ & $22,91 \mathrm{a}$ \\
10 & $3,33 \mathrm{a}$ & $0,88 \mathrm{a}$ & $24,15 \mathrm{a}$ \\
15 & $3,42 \mathrm{a}$ & $0,91 \mathrm{a}$ & $34,04 \mathrm{a}$ \\
\hline Varietas & & & $22,49 \mathrm{a}$ \\
Numbu & $2,15 \mathrm{~b}$ & $0,56 \mathrm{~b}$ & $33,08 \mathrm{a}$ \\
Keller & $3,52 \mathrm{a}$ & $0,99 \mathrm{a}$ & $21,94 \mathrm{a}$ \\
Wray & $2,85 \mathrm{a}$ & $0,74 \mathrm{~b}$ & 18,03 \\
\hline Nilai BNJ 0,05 & 0,70 & 0,21 & \\
\hline
\end{tabular}

Keterangan: Angka-angka yang diikuti oleh huruf yang sama pada kolom dan perlakuan yang sama berbeda tidak nyata menurut uji BNJ pada taraf $5 \%$. 
bobot batang tanaman sorgum manis dimana didapatkan bobot batang segar tertinggi terdapat pada perlakuan dosis pupuk kandang ayam 15 ton $\mathrm{ha}^{-1}$, karena memiliki dosis pupuk yang besar sehingga mampu lebih baik dalam menyerap unsur hara lebih banyak dan daya pegang air yang lebih baik.

Perlakuan bahan organik juga tidak memberikan pengaruh yang nyata terhadap bobot kering tanaman. Namun penggunaan varietas memberikan pengaruh yang nyata terhadap bobot kering tanaman (Tabel 5). Hasil terbaik ditunjukan oleh varietas Keller. Hal ini sejalan dengan pernyataan Sunyoto dan Kamal (2009) dalam Yuliasari (2013) bahwa perbedaan genotipe sorgum menentukan perbedaan tinggi tanaman dan bobot kering brangkasan tanaman sorgum.

Hasil pengamatan pada panjang malai ternyata tidak terdapat pengaruh yang nyata dari perlakuan bahan organik dan penggunaan varietas (Tabel 5). Menurut Safitri et al. (2010) hal ini terjadi disebabkan pada saat pembentukan bunga dan biji seluruh seluruh unsur hara dan air dimanfaatkan tanaman untuk membentuk karbohidrat sehingga tidak mempengaruhi panjang malai.

Hasil penelitian juga menunjukkan bahwa perlakuan bahan organik dan penggunaan varietas memberikan pengaruh yang nyata terhadap jumlah biji per malai, bobot biji per malai dan bobot 100 butir (Tabel 6, 7 dan 8). Terdapat interaksi antara perlakuan bahan organik dan penggunaan varietas. Kombinasi perlakuan terbaik ditunjukkan oleh varietas numbu dengan perlakuan 15 ton ha-1. Hal ini didukung oleh pendapat Sadjad (1993), bahwa perbedaan daya tumbuh antar varietas yang berbeda ditentukan oleh faktor genetiknya. Selain itu, potensi gen dari suatu tanaman akan lebih maksimal jika didukung oleh faktor lingkungan.
Penelitian ini mengamati 2 komponen yaitu komponen pertumbuhan dan komponen hasil. Komponen pertumbuhan meliputi tinggi tanaman, jumlah daun dan diameter batang. Komponen hasil meliputi bobot brangkasan basah, bobot brangkasan kering, panjang malai, jumlah biji per malai, bobot biji per malai dan bobot 100 butir.

Hasil penelitian menunjukkan bahwa pada komponen pertumbuhan, rata-rata petumbuhan terbaik ditunjukkan oleh perlakuan 15 ton $\mathrm{ha}^{-1}$ namun tidak berbeda nyata dengan perlakuan 10 ton ha-1 (Tabel 2, 3 dan 4). Hal ini sejalan dengan hasil penelitian Safitri et al. (2010) bahwa pemberian pupuk kandang ayam dengan dosis 10 ton ha ${ }^{-1}$ dan 15 ton ha ${ }^{-1}$ lebih banyak memperbaiki sifat fisik, daya pegang air ataupun aerasi yang menuju ke arah yang lebih baik sehingga menunjang perkembangan akar yang berfungsi untuk menyerap hara yang lebih banyak. Penggunaan varietas yang memberikan hasil terbaik ditunjukkan oleh varietas Keller namun tidak berbeda nyata dengan Wray ( Tabel 2, 3 dan 4).

Hal ini sejalan dengan hasil penelitian Tola et al. (2007) bahwa secara keseluruhan menunjukkan bahwa penggunaan pupuk bokashi kotoran sapi memberikan pengaruh yang sangat nyata terhadap tinggi tanaman, jumlah daun, berat tongkol, berat basah pipilan, dan berat kering pipilan.

Pada komponen hasil rata-rata hasil terbaik ditunjukkan oleh perlakuan 15 ton ha-1 dan berbeda nyata dengan perlakuan 10 ton ha-1 (Tabel 6,7 dan 8). Pengunaan varietas Keller memberikan hasil terbaik pada komponen hasil bobot basah tanaman dan bobot kering tanaman (Tabel 5). Namun pada komponen hasil jumlah biji per malai, bobot biji per malai dan bobot 100

Tabel 6. Pengaruh bahan organik dan varietas terhadap jumlah biji/ malai tanaman sorgum

\begin{tabular}{|c|c|c|c|c|}
\hline \multirow{3}{*}{ Varietas } & \multicolumn{4}{|c|}{ Dosis Bahan Organik (ton ha ${ }^{-1}$ ) } \\
\hline & 0 & 5 & 10 & 15 \\
\hline & \multicolumn{4}{|c|}{ 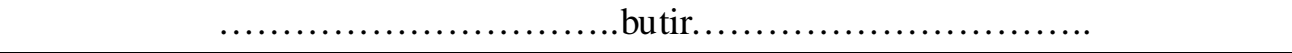 } \\
\hline \multirow[t]{2}{*}{ Numbu } & $2151,33(b)$ & 2284(b) & $3032,67(b)$ & $4770,33(a)$ \\
\hline & A & A & A & A \\
\hline \multirow[t]{2}{*}{ Keller } & $1028,33(\mathrm{a})$ & $1277,33(\mathrm{a})$ & $1641,67(a)$ & $2071(a)$ \\
\hline & A & A & $\mathrm{B}$ & $\mathrm{B}$ \\
\hline \multirow[t]{2}{*}{ Wray } & $1288(\mathrm{a})$ & $1455,67(a)$ & $1741,33(a)$ & 2156,67 (a) \\
\hline & A & A & $\mathrm{B}$ & B \\
\hline
\end{tabular}

BNJ 0,05

1255,80

Keterangan: Angka-angka yang diikuti huruf yang sama tidak berbeda nyata menurut uji BNJ pada $\alpha 5 \%$ huruf kecil untuk perbandingan horizontal, huruf besar untuk perbandingan vertikal 
Tabel 7. Pengaruh bahan organik dan varietas terhadap bobot biji/malai tanaman sorgum

\begin{tabular}{|c|c|c|c|c|}
\hline \multirow{3}{*}{ Varietas } & \multicolumn{4}{|c|}{ Dosis Bahan Organik (ton ha ${ }^{-1}$ ) } \\
\hline & 0 & 5 & 10 & 15 \\
\hline & \multicolumn{4}{|c|}{ 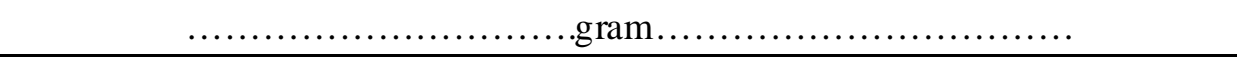 } \\
\hline \multirow[t]{2}{*}{ Numbu } & $50,17(b)$ & $55,07(b)$ & 78,73(b) & $137,77(\mathrm{a})$ \\
\hline & A & A & A & A \\
\hline \multirow[t]{2}{*}{ Keller } & $14,27(\mathrm{a})$ & $20,1(\mathrm{a})$ & $32,83(\mathrm{a})$ & $41,93(\mathrm{a})$ \\
\hline & A & A & $\mathrm{B}$ & $\mathrm{B}$ \\
\hline \multirow[t]{2}{*}{ Wray } & $16,43(\mathrm{a})$ & $24,43(\mathrm{a})$ & $36,1(\mathrm{a})$ & $46,03(\mathrm{a})$ \\
\hline & A & A & $\mathrm{B}$ & $\mathrm{B}$ \\
\hline
\end{tabular}

BNJ $0,05 \quad 36,26$

Keterangan: Angka-angka yang diikuti huruf yang sama tidak berbeda nyata menurut uji BNJ pada $\alpha 5 \%$ huruf kecil untuk perbandingan horizontal, huruf besar untuk perbandingan vertikal

Tabel 8. Pengaruh bahan organik dan varietas terhadap bobot 100 butir tanaman sorgum

\begin{tabular}{|c|c|c|c|c|}
\hline \multirow{3}{*}{ Varietas } & \multicolumn{4}{|c|}{ Dosis Bahan Organik (ton ha ${ }^{-1}$ ) } \\
\hline & $\sigma$ & 5 & 10 & 15 \\
\hline & \multicolumn{4}{|c|}{$\ldots \ldots \ldots \ldots \ldots \ldots \ldots \ldots \ldots \ldots, g r a m \ldots \ldots \ldots \ldots \ldots \ldots \ldots \ldots \ldots$} \\
\hline \multirow[t]{2}{*}{ Numbu } & $2,29(\mathrm{~b})$ & $2,33(b)$ & $2,46(b)$ & $2,86(a)$ \\
\hline & A & A & A & A \\
\hline \multirow[t]{2}{*}{ Keller } & $1,39(\mathrm{~b})$ & $1,57(b)$ & $1,95(\mathrm{a})$ & $2,03(\mathrm{a})$ \\
\hline & $\mathrm{A}$ & $\mathrm{A}$ & $\mathrm{B}$ & $\mathrm{B}$ \\
\hline \multirow[t]{2}{*}{ Wray } & $1,28(\mathrm{~b})$ & $1,64(b)$ & 2,08 (a) & $2,13(\mathrm{a})$ \\
\hline & $\mathrm{A}$ & A & $\mathrm{B}$ & $\mathrm{B}$ \\
\hline BNJ 0,05 & 0,33 & & & \\
\hline
\end{tabular}

Keterangan: Angka-angka yang diikuti huruf yang sama tidak berbeda nyata menurut uji BNJ pada $\alpha 5 \%$ huruf kecil untuk perbandingan horizontal, huruf besar untuk perbandingan vertikal

butir pada kadar air $14 \%$ varietas Numbu memberikan hasil terbaik.

Hasil penelitian ini sama dengan pernyataan Rahmawati (2013) yang menyatakan bahwa umumnya tanaman yang memiliki pertumbuhan tanaman lebih tinggi akan diikuti oleh jumlah daun yang lebih banyak dan diameter batang yang lebih besar serta tingkat kehijauan daun yang tinggi karena penyerapan energi cahaya untuk berlangsungnya metabolisme dalam organ tumbuhan lebih baik dan dapat terpenuhi, sehingga berpengaruh terhadap hasil tanaman tersebut.

Hasil penelitian menunjukkan bahwa tinggi tanaman menberikan kolerasi terhadap jumlah daun, semakin tinggi tanaman maka jumlah daun tanaman semakin banyak. Diameter dan jumlah daun memberikan kolerasi terhadap jumlah biji hal ini dikarenakan diameter batang tanaman yang besar menunjukkan bahwa serapan unsur hara optimal. Selain itu jumlah daun yang banyak menyebabkan proses fotosintesis tinggi dan menghasilkan fotosintat yang tinggi. Fotosintat ini kemudian disimpan dalam bentuk biji pada malai sorgum. Jumlah biji/ malai memberikan kolerasi terhadap bobot biji per malai. Semakin banyak jumlah biji pada malai maka semakin berat bobot yang dihasilkan.

Penerapan sistem teknologi budidaya dengan pemberian bahan organik dengan mengkombinasikan varietas-varietas unggul yang memiliki kelebihan sesuai genetik masing-masing akan berdampak positif terhadap hasil tanaman sorgum. Varietas Numbu yang ditanam dengan menggunakan jarak tanam $80 \mathrm{~cm}$ x $20 \mathrm{~cm}$ maka akan menghasilkan 62.500 populasi tanaman pada setiap hektarnya. Sehingga pada penggunaan dosis 0 ton hadengan bobot 50,17 gram per malai setara dengan hasil 3,1 ton $\mathrm{ha}^{-1}$. Pada penggunaan dosis 5 ton ha ${ }^{-1}$ dengan 
bobot 55,07 gram per petak setara dengan hasil 3,4 ton ha $^{-1}$, sedangkan pada dosis 10 ton ha ${ }^{-1}$ dengan bobot 78,73 gram per petak setara dengan hasil 4,9 ton ha. Hasil produksi tertinggi pada dosis 15 ton ha ${ }^{-1}$ dengan bobot 137,77 gram per malai setara dengan 8,6 ton ha-1.

Jika dilihat dari asumsi hasil yang diperoleh maka penggunaan dosis 15 ton ha ${ }^{-1}$ bisa dijadikan pilihan yang tepat, karena peningkatan produksi yang didapat meningkat $74 \%$ dari dosis 10 ton ha $^{-1}$. Peningkatan dosis bahan organik memang meningkatkan biaya produksi, namun jika melihat hasil yang diperoleh maka bisa menutupi biaya produksi. Hal ini akan sangat menguntungkan apabila diterapkan langsung di masyarakat apalagi dengan kemampuan tanaman sorgum untuk tumbuh kembali setelah dipanen (ratoon) sehingga lebih memaksimalkan hasil yang didapat dengan mengurangi modal yang berkaitan dengan efisiensi penggunaan benih untuk pertanaman selanjutnya.

Penggunaan varietas yang akan ditanam juga harus memperhatikan tujuan dari penggunaan, apabila selanjutnya berangkasan atau biomassa yang dihasilkan ditujukan untuk pakan ternak maka varietas Keller dan Wray yang cocok untuk ditanam. Pada jarak tanam yang sama dengan Numbu varietas Keller bisa menghasilkan biomassa sebesar 61 ton ha $^{-1}$ atau meningkat $76 \%$ jika dibandingkan dengan Numbu yang hanya 35 ton ha- ${ }^{-1}$. Sedangkan varietas Wray hanya mengalami peningkatan $32 \%$ dengan hasil 46 ton/ha jika dibandingkan dengan Numbu. Berdasarkan hal ini maka penggunaan varietas harus memperhatikan tujuan penanaman. Numbu mempunyai potensi hasil panen yang tinggi karena ukuran biji yang lebih besar jika dibandingkan Keller dan Wray.

\section{KESIMPULAN}

Berdasarkan hasil dan pembahasan yang telah diuraikan dapat diambil kesimpulan bahwa : (1) Aplikasi bahan organik meningkatkan pertumbuhan dan hasil tanaman sorgum. Bobot biji basah per malai tertinggi dicapai pada dosis 15 ton ha-1. (2) Varietas Numbu menunjukkan keragaan komponen hasil bobot biji basah per malai terbaik, sedangkan produksi brangkasan terbaik ditunjukkan oleh varietas Keller dan Wray. (3) Kombinasi penggunaan bahan organik dan varietas yang tepat untuk bobot biji sorgum basah tertinggi adalah dosis 15 ton/ha dengan varietas Numbu dengan bobot 137,77 gram per malai atau setara dengan 8,6 ton ha ${ }^{-1}$.

\section{DAFTAR PUSTAKA}

Harjadi, W. 1993. Ilmu Kimia Analitik Dasar. PT Gramedia Pustaka Utama. Jakarta.
Nasaruddin. 2010. Dasar-Dasar Fisiologi Tumbuhan. Penerbit Yayasan Forest Indonesia dan Fakultas Pertanian Unhas. Makassar.

Purwaningsih, Y. 2008. Ketahanan Pangan: Situasi, Permasalahan, Kebijakan dan Pemberdayaan Masyarakat. Jurnal Ekonomi Pembangunan. Surakarta: Balai Penelitian dan Pengembangan Ekonomi Fakultas Ekonomi Universitas Muhammadiyah Surakarta. 9(1):1-27.

Prihastanti, E. 2010. Pembibitan Jarak Pagar (Jatropha curcas L. ) pada Jenis Tanah dan Penambahan Kompos yang Berbeda. Buletin Anatomi dan Fisiologi. 18(2)

Rahmawati, A. 2013. Respons Beberapa Genotipe Sorgum (Sorghum bicolor [L] Moench) yang Ditumpangsarikan dengan Ubikayu (Manihot esculanta Crantz). Skripsi. Uniersitas Lampung. Lampung. Hal 36.

Sadjad, S. 1993. Dari Benih Kepada Benih. Gramedia, Jakarta.

Safitri, R., N Akhir, dan I Suliansyah. 2010. Pengaruh Jarak Tanam dan Dosis Pupuk Kandang Ayam Terhadap Pertumbuhan dan Hasil Tanaman Sorgum Manis (Sorghum bicolor [L.] Moench). Jurnal Jerami. 3(2)

Sirappa, MP. 2003. Prospek Pengembangan Sorghum di Indonesia sebagai Komoditas Alternatif untuk Pangan, Pakan dan Industri. J. Litbang Pertanian, 22(4):133-140

Sucipto. 2010. Efektifitas Cara Pemupukan dan Hasil Beberapa Varietas Sorghum Manis. Jurnal Embriyo. 7 (2)

Tola., Faisal Hamzah, Dahlan, dan Kaharuddin. 2007. Pengaruh Penggunaan Dosis Pupuk Bokashi Kotoran Sapi Terhadap Pertumbuhan Dan Produksi Tanaman Jagung. Jurnal Agrisistem, 3 (1)

Yuliasari, R. 2013. Distribusi Bahan Kering Beberapa Genotipe Sorgum (Sorghum bicolor [L] Moench) yang Ditumpangsarikan dengan Ubikayu (Manihot esculanta Crantz). Skripsi. Universitas Lampung. Lampung. Hal 32-33.

Zulkifli., Herman. 2012. Respon Jagung Manis (Zea mays Saccharata Stut) Terhadap Dosis Dan Jenis Pupuk Organik. Jurnal Agroteknologi, 2(2):33-36 